\title{
The German-Tanzanian Tendaguru Expedition 2000
}

\author{
Wolf-Dieter Heinrich ${ }^{1}$, Robert Bussert ${ }^{2}$, Martin Aberhan ${ }^{1}$, Oliver Hampe ${ }^{1}$, Saidi Kapilima ${ }^{3}$, \\ Eckart Schrank $^{2}$, Stephan Schultka ${ }^{1}$, Gerhard Maier ${ }^{4}$, Emma Msaky $^{5}$, Benjamin Sames ${ }^{6}$ \\ \& Remigius Chami ${ }^{7}$
}

With 1 figure, 1 table, and 2 plates

\begin{abstract}
The celebrated fossil locality of Tendaguru (Tanzania, East Africa) has been well known for its unique Late Jurassic dinosaur assemblages since the early decades of the $20^{\text {th }}$ century. Recently, within the scope of the German-Tanzanian Tendaguru project, an expedition returned to Tendaguru with the aim of collecting microvertebrates, micro- and macroinvertebrates. plant fossils and new sedimentological and stratigraphical data. Applying a multidisciplinary research approach, the data collected were used to address various controversial issues regarding the Tendaguru Beds. These include their exact age, depositional environments and reconstructions of the palaeoecosystems in which the dinosaurs lived.

Field work resulted in a new standard section for the Tendaguru Beds. Preliminary biostratigraphic results, based on ammonites, charophytes and palynomorphs, support a Late Kimmeridgian age for the Nerinea Bed, an early Tithonian age for the Trigonia smeei Bed, and an Early Cretaceous (possibly Valanginian to Hauterivian) age for the Trigonia schwarzi Bed. Facies analysis of the Tendaguru Beds indicates environments ranging from storm- and tide-influenced, siliciclastic coastal barrier systems, ooid sand bar complexes and backbarrier tidal flats to sabkha-like coastal plains with brackish lakes and pools. Sedimentological indicators of palaeoclimate and palynological data point to a subtropical to tropical climate with pronounced dry seasons. In concert with sedimentological data. quantitative palaeoecological analysis of macroinvertebrates helped to finetune understanding of environmental factors such as substrate conditions, salinity, sedimentation rate and water depth. Along with abundant microvertebrate remains and fragments of fusain and cuticles, these new data have considerably improved our knowledge of the launa and flora found in the Tendaguru Beds, and provide a solid basis for developing a better understanding of the Late Jurassic and Early Cretaceous Tendaguru palaeoecosystems.

To put the German-Tanzanian Tendaguru expedition in perspective, a brief review of previous activities is given and future research objectives are outlined.
\end{abstract}

Key words: Tendaguru, Tanzania, Gondwana, Mesozoic, Lithostratigraphy, Sedimentology, Palaeozoology, Palacobotany. Palynology. Palaeoecology, Biostratigraphy

\section{Zusammenfassung}

Die berühmte Fossilfundstätte Tendaguru (Tansania, Ostafrika) ist seit Anfang des 20. Jahrhunderts weltweit für ihre Dinosaurier aus der späten Jura-Zeit bekannt. Im Rahmen des Deutsch-Tansanischen Tendaguru Projekts fand im August und September 2000 eine Expedition in die Umgebung des Tendaguru-Hügels statt. Ziel der Expedition war es, umfangreiche Fossilaufsammlungen von Mikrovertebraten, Mikro- und Makroinvertebraten und pflanzlichen Fossilien durchzuführen und neuc sedimentologische und stratigraphische Daten aufzunehmen. Unter Anwendung eines interdisziplinären Forschungsansatzes wurden mit den gesammelten Daten verschiedene, bisher kontrovers diskutierte Aspekte der Tendaguru-Schichten untersucht. Offene Fragen umfassten die genaue Alterseinstufung, eine Interpretation der Ablagerungsräume und die Rekonstruktion der Paläoökosysteme, in denen die Dinosaurier lebten.

Die erste Auswertung der Geländedaten führte zu einem neuen Standardprofil für die Tendaguru-Schichten. Vorläufige biostratigraphische Ergebnisse, die auf Ammoniten, Charophyten und Palynomorphen basieren, sprechen für ein Ober-Kimmeridgium Alter der Nerineen Schicht, Unteres Tithonium für die Trigonia smeei Schicht und Untere Kreidc (möglicherweise Valanginium bis Hauterivium) für die Trigonia schwarzi Schicht. Die Lebens- und Ablagerungsräume der Tendaguru-Schichten reichten von sturm- und gezeitenbeeinflussten, küstennahen, siliziklastischen Barrieresystemen und Kalkooid-Barren übcr

Museum für Naturkunde, Zentralinstitut der Humboldt-Universität zu Berlin, Institut für Paläontologie. Invalidenstraße 43, D-10115 Berlin, Germany.

2 Institut für Angewandte Geowissenschaften, Technische Universität Berlin, Sekr. BH 2, Ernst-Reuter-Platz 1, D-10587 Berlin, Germany.

3 Department of Geology, University of Dar es Salaam, P.O. Box 35052, Dar es Salaam, Tanzania.

4 728-71 Avenue SW Calgary, Alberta, Canada T2V 0R4.

5 Tanzania Petroleum Development Corporation, P.O. Box 5233, Dar es Salaam, Tanzania.

${ }^{6}$ Institut für Paläontologie, Freie Universität Berlin, Malteserstr. 74-100, D-12249 Berlin. Germany.

7 Ministry of Natural Resources and Tourism, Antiquities Units, P.O. Box 2280. Dar es Salaam, Tanzania. Received June 2001, accepted July 2001 
ausgedehnte Watıflächen bis zu sabkha-artigen Küstenebenen mit brackischen Seen und Tümpeln. Sedimentologische Anzeiger des Paläoklimas und palynologische Daten sprechen für ein subtropisches bis tropisches Klima mit ausgeprägten Trockenzeiten. Im Verbund mit sedimentologischen Daten ermöglicht die quantitative paläoökologische Analyse der Makroinvertebraten eine genauere Charakterisierung wichtiger physikalischer Umweltparameter wie Substrateigenschaften, Salinität, Sedimentationsrate und Bathymetrie. Zusammen mit den häufig vorkonmenden Mikrovertebraten und Bruchstücken von Fusit und Cuticulen haben diese neu gewonnenen Daten die Kenntnisse über die Faunen und Floren der Tendaguru-Schichten erheblich erweitert und liefern die Basis für ein besseres Verständnis der in den Ablagerungen dokumentierten Ökosysteme aus Jura- und Kreidezeit.

Neben einem kurzen Abriss der Forschungsgeschichte werden die für die Zukunft geplanten Forschungsaktivitäten dargestellt.

Schlüsselwörter: Tendaguru. Tansania. Gondwana. Mesozoikum. Lithostratigraphie. Sedimentologie. Paläozoologie, Paläobotanik. Palynologie. Paaläoökologie. Biostratigraphie

\section{Introduction}

The locality o: Tendaguru is situated roughly 60 kilometers nor thwest of the seaport of Lindi in southeastern Tanzania (Fig. 1. PI. 1: 1). Following the excavations of the German Tendaguru Expedition (1909-913). the site became well known for its diverse Late Jurassic dinosaur assemblages. including sauropods, theropods. and ornithischians. Compared to dinosaurs, however. research on associated organisms such as plants, microvertebrates and microfossils (e.g.. ostracods, charophytes, palynomorphs) has long taken a back seat, owing to the lack of such fossils.

During the ast five years, in cooperation with other German and Tanzanian universities and institutions, a ntw program of research on Tendaguru was estallished by the Museum für Naturkunde, Berliı, based mainly on material collected by the German Tendaguru Expedition (1909-1913). Several fossil groups hitherto unknown from Tendaguru have been discovered. Moreover, new data on the taphonomy and physiology of the Tendaguru dinosaurs were obtained using modern techniques such as computer tomography, photogrammetry and laser scanning.

These activi ies fuelled several years of scientific research and provided exciting new insights into the Late Jurassic to Early Cretaceous fauna and flora of Tendaguru and the environments in which they existed. However, intensive research has not only yielded new insights, but also revealed further unsolved questions and uncovered fundamental gaps in our knowledge. For example. the exact age of the Tendaguru Beds is still uncertain and needs additional highly-focused investigations. This is the only way in which correlation of the Tendaguru Beds with the Jurassic and Cretacenus orthostratigraphy can be achieved. New detailed recording of the sections of the old excavation sites is required to under- stand the taphonomy and palaeoecology of the dinosaurs. So far, a modern quantitative palaeocological analysis of macroinvertebrates is lacking. In addition, the associated microfaunal elements and plants still remain largely unknown. Knowledge of these elements is necessary, however. to understand the environment in which the dinosaurs lived. It is clear that without a new field campaign in Tanzania, many important questions concerning the geology and biostratigraphy of Tendaguru Beds, palaeobiology of the Tendaguru dinosaurs, and the ecosystems in which they lived cannot be answered.

For these reasons, efforts have been intensified in recent years to return to Tendaguru and explore the possibility of renewed excavation and geological research. These efforts were successful in 2000. In August and September 2000, a group of German, Tanzanian, and Canadian scientists returned to Tendaguru with the aim of collecting microvertebrates, invertebrates, plant fossils and new sedimentological and stratigraphical data. This was the first large scale field study since the original excavations during the early decades of the $20^{\text {th }}$ century.

The aim of the following account is: (1) to provide a brief review of previous research carried out at the locality of Tendaguru; (2) to describe the logistics of the German-Tanzanian Tendaguru expedition 2000; (3) to present preliminary results of the field party 2000 ; and (4) to outline future research that should be carried out at Tendaguru.

\section{Earlier activities}

Tendaguru was visited by the German Tendaguru Expedition 1909-1913 and by the British East Africa Expedition 1924-1931 (for details see Heinrich 1999a). The results of the German expedition were published in voluminous mono- 


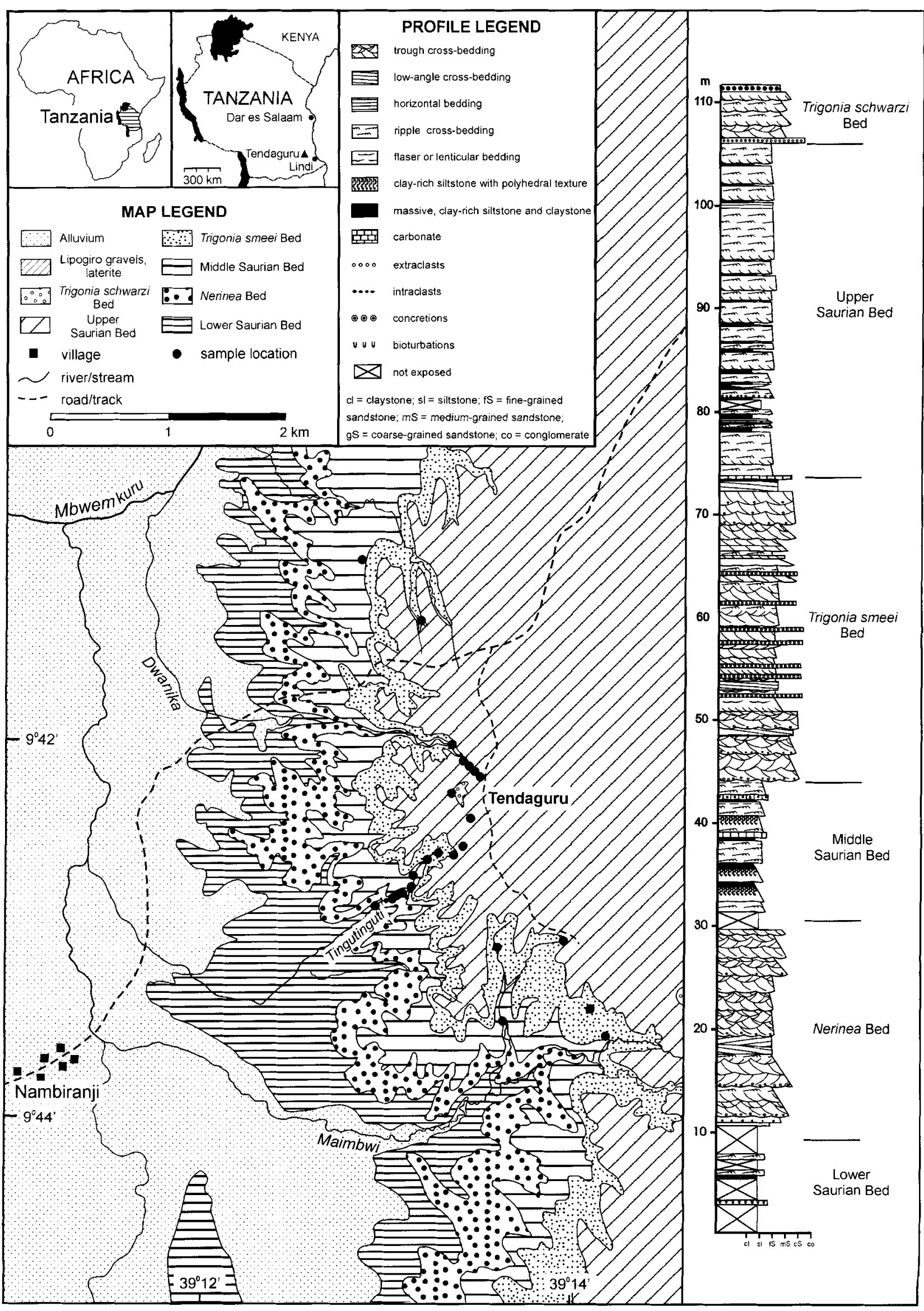

Fig. 1. Geological map of the Tendaguru area and section of the Tendaguru Beds, based on Hennig (1914a), Janensch (1914a, $1914 c, 1925)$ and new data of the German-Tanzanian Tendaguru Expedition 2000. 
graphs as well as papers in other scientific journals. It was established that the Tendaguru Beds are made up cf three dinosaur-bearing strata. the Lower, Middle, and Upper Saurian Bed, and three marine sandstone units, the Nerinea Bed. Trigonia smeei Bed, and the Trigonia schwarzi Bed (Janensch 1914c). The marine strata have yielded thousands of invertebrates, including corals (e.g., Dielrich 1926), bivalves (e.g., Lange 1914, Hennig 1914a. Kitchin 1929, Dietrich 1927a, 1933, Aitken 1961), gastropods (Dietrich 1914) cephalopods (e.g., Zwierzcycki 1914. Dietrich 1925, 1933), brachiopods (Lange 1914. Hennig 1937), decapods (Beurlen 1933) and echinoderms (Dietrich 1933, Sieverts-Doreck 1939). This marine invertebrate assemblage was the basis for the biostratigraphic evaluation of the Tendaguru Beds. A poorly preserved conifer cone from the Upper Saurian Bed was described as Conites araucarioides by Gothan (1927).

There was considerable controversy concerning the age of the Tendaguru Beds and their depositional environments. The Trigonia schwarzi Bed is known to be lower Lower Cretaceous. while the unclerlying part of the sequence is equated with the Late Jurassic (Aitken 1961). Environmental interpretations of the dinosaurbearing beds range, for example, from a shallow backbarrier lagoon (Janensch 1914c), a flat coast with lagoons or swamps (Dietrich 1925) to an estuarine environment with fluctuating salinities (Parkinson 1930).

From the excavations of the German expedition, Tendaguı u is primarily known for its diverse Late Jur assic dinosaur assemblages including sauropods (Brachiosaurus, Barosaurus, Dicraeosaurus, Janenschia), theropods (e.g., Elaphrosaurus, Ceratosaurus, Allosaurus, etc.), and ornithischians (Dryosaurus $[=$ Dysalotosaurus], Kentrosaurus) which were the main focus of palaeontological investigations in the past (Heinrich 1999). It is noteworthy, that Gross (1934), in fact, provided an early account on bone histology of Tendaguru dinosaurs. Several dinosaur skeletons were set up for display in the Museum für Naturkunde in Berlin including Kentrosaurus (1924), Elaphrosaurus (1926). Dicraeosaurus (1931), Brachiosaurus (1937), and Dysalotosaurus, now Dryosaurus (1958). The majority of dinosaur finds come from the Middle and Upper Saurian Beds: the Lower Saurian Bed yielded only a few specimens (Janensch 1961). Compared to dinosaurs, other vertebrate groups are distinctly under-represented due to collecting bias. The associated vertebrate fauna, collected between 1909 and 1913 includes sharks (Sphenodus sp. [=Orthacodus $]$ ) and neopterygian fish (Hennig 1914b), indeterminate crocodiles (Janensch 1914b), pterosaurs (Reck 1931) and even a mammal (Brancatherulum tendagurense: Dietrich 1927b, Simpson 1928).

The last three decades have seen a resurgence in the scientific study of Tendaguru dinosaurs. After a long break, a Canadian and Tanzanian team returned to Tendaguru in 1977 and 1978 (Maier 1997, 2000) to look for dinosaurs, followed by a German-Tanzanian team in 1994 (Zils et al. 1995). The reexamination of dinosaurs (e.g., Elaphrosaurus, Kentrosaurus, Dryosaurus: Galton 1977, 1981, 1982a, 1982b; Brachiosaurus: Paul 1988, Christian \& Heinrich 1998, Christian et al. 1999a, 1999b), pterosaurs (Dsungaripterus? brancai: Galton 1980, now considered a nomen dubium by Unwin \& Heinrich 1999) and the Tendaguru mammal Brancatherulum tendagurense (Heinrich 1991) resulted in the modification of earlier views. Striking similarities between the Late Jurassic dinosaur faunas of the Morrison Formation and the Tendaguru Beds were interpreted as evidence for the existence of land connections and dispersal routes between Laurasia and Gondwana (Galton 1977, 1982a), as formerly suggested by Fraas (1908) and Janensch (1914c).

A program of microvertebrate sampling from matrix of the Middle and Upper Saurian Beds collected by the German Tendaguru Expedition between 1909 and 1913 was established in the 1990 s at the Museum für Naturkunde, Institut für Paläontologie. It resulted in the recovery of bones and teeth of a diverse, hitherto unknown assemblage of smaller land vertebrates, among them lizards (Paramacellodidae gen. et sp. indet.: Broschinski 1999), crocodiles (?Bernissartia) and pterosaurs (determined by Reck 1931 as Rhamphorhynchus tendagurensis, Pterodactylus maximus, Pterodactylus brancai, Pterodactylus arningi; now considered nomina dubia and tentatively assigned to Tendaguripterus recki by Unwin \& Heinrich 1999). Special attention was given to the recovery of fossil remains of mammals and led to the discovery of Tendagurodon janenschi (Tricondonta), Tendagurutherium dietrichi ('Eupantotheria'), and Staffia aenigmatica, the first record of a haramiyid in Gondwana (Heinrich 1998, 1999b). In addition, teeth of theropod, sauropod and ornithischian dinosaurs were obtained.

Reexamination of the material previously assigned to Lepidotus aff. minor (Hennig 1914b) 
resulted in the discovery of a new neopterygian fish taxon Lepidotus tendaguruensis (Arratia \& Schultze 1999).

A new research program on Tendaguru sauropods that took advantage of new techniques such as laser scanning, photogrammetry, and computer tomography provided new insights regarding the posture, body weight, and physiology of these huge dinosaurs (Gunga et al. 1995, 1999; Christian \& Heinrich 1998, Christian et al. 1999a, Perry \& Reuter 1999, Wiedemann et al. 1999). The bone histology of Barosaurus, Brachiosaurus, Dicraeosaurus, and Janenschia was intensively studied by Sander (1999, 2000) providing important data on the life history of the sauropods from Tendaguru. To analyse ontogenetic changes in bone histology, femora of Dryosaurus lettowvorbecki were studied microscopically by Chinsamy (1995). Speed estimates were calculated for Brachiosaurus brancai, Barosaurus africanus, Dicraeosaurus hansemanni, Dicraeosaurus sattleri, and Janenschia robusta (Christian et al. 1999b). Based on material housed in the Museum für Naturkunde Berlin, Bonaparte et al. (2000) restudied Janenschia and described a new sauropod dinosaur from the Tendaguru Beds: Tendaguria tanzaniensis.

The comparative anatomy of the Tendaguru dinosaurs has been examined in considerably greater detail than the taphonomy of the excavation sites. Unpublished quarry maps from the German Tendaguru Expedition offer insights, but there is presently no consensus on a taphonomic model. A range of skeletal disarticulation preceded final interment, from incomplete skeletons to isolated bones. It was found that accumulations of sauropod bones in the Middle and Upper Saurian Beds are dominated by adult individuals, while juveniles are scarce or absent (Heinrich 1999a). Bone assemblages were formed over a great period of time in the Late Jurassic, as a series of superimposed dinosaurbearing strata indicates. An ${ }^{235} \mathrm{U} / 207 \mathrm{~Pb}$ age determination based on a bone sample of an ilium of Brachiosaurus brancai from the Upper Saurian Bed suggests that the age of this dinosaur-bearing deposit falls in the range of $140-150 \mathrm{Ma}$ (Romer 2000, 2001).

Samples taken from Tendaguru material stored in the Museum für Naturkunde Berlin have yielded two palynological assemblages: first, a largely non-marine AnapiculatisporitesDensoisporites-Trisaccites assemblage from the Middle Saurian Bed, and secondly, a marine Barbatacysta-Pareodinia assemblage from the overly- ing Trigonia smeei Bed, which suggest a Kimmeridgian-Tithonian age for these parts of the section (Schrank 1999). Samples from the Upper Saurian Bed yielded some triaperturate angiosperm pollen associated with fungal palynomorphs (Rhizophagites, hyphae), indicating contamination from recent and subrecent sources. Prior to this, a poorly preserved microflora containing, among others, Classopollis torosus and problematic (contamined?) angiosperm pollen, was reported from the Upper Saurian Bed (Jarzen 1981). Charophytes indicate a Kimmeridgian age (Schudack 1999) and ostracods a late Kimmeridgian age for the Middle Saurian Bed (Schudack \& Schudack 2001).

Specimens of silicified wood, collected by the German expedition in the Tendaguru area, represent typical conifers, including Taxodiaceae, Cupressaceae and Taxaceae, but also demonstrate the presence of Ginkgoales (Kahlert et al. 1999). However, these findings are possibly erosional relics from Cretaceous or Tertiary strata. Samples from the Middle Saurian Bed, also held in the Museum für Naturkunde, revealed that fusain is very common, but mostly not well preserved, except for one specimen which shows the characteristics of a new species of the Taxodiacean genus Glyptostroboxylon. Naturally macerated cuticles are relatively abundant in matrix of the Middle Saurian Bed and seem, at least in part, to belong to Ginkgophytaleans of the Baiera-Sphenobaiera-group (Kahlert et al. 1999).

Petrographic investigations of samples housed in the Museum für Naturkunde (Bussert 2000) show, that the Middle and the Upper Saurian Beds are composed of calcite-cemented siltstones and fine-grained sandstones. By contrast, the marine intercalations of the Nerinea Bed, Trigonia smeei Bed and the Trigonia schwarzi Bed consist of calcite-cemented, bioclast-rich sandstones, and silicious-sandy limestones. All beds contain high amounts of feldspar. The clay fractions are dominated by smectite, with minor amounts of illite. Samples from the Middle Saurian and the Upper Saurian Bed show traces of gypsum. Both beds contain reworked bones, clayey intraclasts and reworked as well as in situcalcretes. The petrographic studies indicate a seasonal, semiarid palaeoclimate with prolonged droughts and rainy intervals during the deposition of the Tendaguru Beds. These palaeoclimatic conditions were probably an important factor for the accumulation of dinosaur bones in the predominantly continental deposits of the Middle and the Upper Saurian Bed. 
The presented data were the basis of the field work of the Garman-Tanzanian Tendaguru Expedition 2000 of which results are described in more detail in the following account.

\section{Tendaguru 20(10}

\section{Logistics}

An initial agreement on Tanzanian-German cooperation was reached in early 1999, when E. Schrank prese ited drafts of a research proposal to partner ins itutions (Department of Geology of the Univers ty Dar es Salaam, Tanzania Petroleum Develofment Corporation [TPDC]) and authorities that approved research permits (COSTECH. Ministry of Natural Resources and Tourism: Antiquities Units) in Dar es Salaam. The 2000 Expedition. which took place between August $22^{\text {nd }}$ and September $24^{\text {th }} 2000$. consisted initially of twc groups. The first group (R. Bussert, O. Hampe, E. Schrank). arrived in Dar es Salaam on Atgust $22^{\text {nd }}$. and the second group (M. Aberhan, W.-D. Heinrich, B. Sames, St. Schultka), one week later. On August $26^{\text {th }}$. G. Maier from Calgary (Canada) joined the team.

During the week of August $22^{\text {nd }}$ to $29^{\text {th }}$. research clearances were obtained from COST$\mathrm{ECH}$ and the Antiquities Units. These documents permitted the collection of matrix samples and invertebrate fossils, but not dinosaur bones. The expedition equipment, weighing about 450 $\mathrm{kg}$, was cleared through customs at Dar es Salaam airport over the course of one and a half days, three four-wheel drive vehicles and drivers were hired from Evergreen Car Rentals in Dar es Salaam and additional field equipment. tools, and food were purchased, along with topographi- cal maps and aerial photographs. The Immigration Office granted "Resident Class C" status to O. Hampe in his function as scientific coordinator of the expedition. A seasonal insurance policy with the "Flying Doctors of Africa" was taken out for all German participants of the expedition group.

The two Tanzanian partner institutions each seconded one scientist to the expedition: S. Kapilima (University of Dar es Salaam, Dept. of Geology), and E. Msaky (TPDC). Both institutions generously supplied additional drivers and four-wheel drive vehicles. Moreover, R. Chami, Antiquities Units at the National Museum Dar es Saalam joined the team.

The expedition, 16 participants including the five drivers (Table 1), departed Dar es Salaam on August $31^{\text {st. }}$, and arrived at Lindi, a southern seaport about $60 \mathrm{~km}$ southeast of Tendaguru, on the evening of the same day (Pl. 1: 2). Prior to leaving for the field, obligatory visits were made to the Lindi Security Office, Police Department, and the local Immigration Office on September $1^{\text {st }}$.

The expedition left Lindi in the early morning of September $2^{\text {nd }}$ and reached Tendaguru Hill around noon of the same day. A camp site was established at the eastern foot of Tendaguru Hill. It proved impossible to obtain drinking water locally, and weekly trips were made to Lindi to purchase water and fresh food supplies. Dry season temperatures reached from 36 to $39^{\circ} \mathrm{C}$. Detailed field work took place between September $3^{\text {rd }}$ and $17^{\text {th }}$. Daily reconnaissance was undertaken by groups of specialists, both on foot and by vehicle. Fresh stratigraphic sections were exposed in numerous dry streambeds, and measurements, descriptions, and matrix samples as well as bulk collections of macroinvertebrates

Table 1

Participants of the German-Tanzanian Tendaguru Expedition 2000 and their fields of specialisation.

Oliver Hampe

Wolf-Dieter Heinr ch

Martin Aberhan

Stephan Schultka

Eckart Schrank

Robert Busscrt

Benjamin Sames

Saidi Kapilima

Emma Msaky

Gerhard Maier

Remigius Chami

Hassan Kimega

Elvis Mgaya

John Mhina

Omary Kamanya

Yusufu Kabezi
Humboldt-University. Berlin

Humboldt-University. Berlin

Humboldt-University, Berlin

Humboldt-University. Berlin

Technical University. Berlin

Technical University. Berlin

Free University. Berlin

University of Dar es Salaam

Tanzanian Petroleum Development Corporation Calgary. Alberta

Antiquities Units. Dar es Salaam

University of Dar es Salaam

Tanzanian Petroleum Development Corporation

Evergreen Car Rentals

Evergreen Car Rentals

Evergreen Car Rentals
Organisation, Logistics

Early Mammals, Microvertebrates

Molluscs, Palaeoecology

Palaeobotany

Palynology

Sedimentology

Ostracods, Micropalaeontology Invertebrates, Cooperation Partner

Palynofacies

Documentation, History

Archaeology

Driver

Driver

Driver

Driver

Driver 
were obtained. Former quarry sites were relocated and recorded using Global Positioning System devices. The "Executive Office" of the region in Mipingo was visited subsequently to present the objectives of the Tendaguru project. Matrix samples were wrapped and prepared for the return to Dar es Salaam on September $17^{\text {th }}$. The departure from the field occurred on the morning of the $18^{\text {th }}$, one day earlier than scheduled, because of sporadic rainfall. Heavy rain would render the tracks impassable.

The return flight to Berlin was scheduled for September $23^{\text {rd }}$, after the collected samples (nearly one ton) were declared at customs in Dar es Salaam.

The success of the pilot project was guaranteed by the generous support and enthusiastic participation of Tanzanian officials, scientists, and the people of the Tendaguru area. Many corporate and government authorities expressed a strong interest in the project. This gratifying endorsement is an essential foundation to successful, cooperative field work in the future.

\section{Preliminary results}

\section{Sedimentology and lithostratigraphy}

The Tendaguru Beds consist of three finegrained dinosaur-bearing beds (Lower, Middle and Upper Saurian Bed), that are intercalated into sandstone-dominated beds containing mainly marine fauna (Nerinea Bed, Trigonia smeei Bed and Trigonia schwarzi Bed). The finegrained beds are dominated by ripple crossbedded to massive siltstones and small-scale cross-bedded, fine-grained sandstones, with some claystone and carbonate layers. In contrast, the sandstone-dominated beds consist mainly of bioclastic, trough cross-bedded sandstones. Low-angle and ripple cross-bedded sandstones as well as flaser bedded heterolithic layers are also present. Whereas the Trigonia smeei Bed comprises prominent conglomerates and shell beds, the Nerinea Bed contains hummocky cross-bedded sandstones. In the Trigonia smeei Bed, the siliciclastic sediments interfinger with ooid bar complexes. During diminished sediment-influx, the ooid bars were colonised by coral-oyster biostroms (Pl. 1: 7, Pl. 2: 4).

The facies characteristics of the Nerinea Bed (Pl. 1: 3), Trigonia smeei Bed and the Trigonia schwarzi Bed suggest deposition in a near coast, shallow marine environment with evidence of storms and tides (Bussert 2001). The principal lithofacies types represent tidal channel, tidal sand bar or flood and ebb delta deposits. Isolated beach sands are also present. The Trigonia smeei Bed and the Trigonia schwarzi Bed contain tidal flat sediments. Several conglomerates and shell beds in the Trigonia smeei Bed (Pl. 1: 5) and hummocky cross-bedded sandstones in the Nerinea Bed are interpreted as storm deposits. Altogether these sediments indicate deposition in storm- and tide-influenced near coastal barrier systems, with backbarrier tidal flats.

The fine-grained sediments of the Middle Saurian Bed represent, in part, intertidal deposits (Pl. 1: 4). In the upper part of the Middle Saurian Bed single calcrete horizons are present. indicating dry periods in the depositional environment, the appearance of soil forming processes and the dominance of terrestrial conditions. In the Upper Saurian Bed the transition from marine to continental sediments is marked by micritic dolomites. These deposits are overlain by mud- and silt-rich sediments, that represent a sabkha-like coastal plain with lakes and pools, that were incised by small fluviatile channels (Pl. 1: 8).

During transgressive periods, the barrier systems migrated landward, and incised deeply into tidal flat and coastal plain sediments. The following regressive sequences are characterised by a nearly complete sequence from shallow marine sandstones to tidal flat and beach sediments, topped by fine-grained sabkha and coastal plain sediments.

Sedimentological indicators of the palaeoclimate, such as high amounts of feldspars in the sandstones, the dominance of smectite and illite in the clay fractions and the presence of calcretes in the Middle and Upper Saurian Bed point to a seasonal, subtropical to tropical climate with pronounced dry seasons during deposition.

Field work in August and September 2000, resulted in a new standard section for the Tendaguru Beds (Fig. 1). The stratigraphical terminology employed for the Tendaguru Beds in the recent literature is not uniform. Designations such as Tendaguru Beds, Trigonia schwarzi Bed, or Middle Saurian Bed (e.g., Aitken 1961, Russell et al. 1980), which refer to the field work of the German Tendaguru Expedition (e.g., Tendaguru Schichten, Trigonia schwarzi Schicht, etc.: e.g., Hennig 1914c, Janensch 1914c), do not conform to the regulations of the International Union of Geological Sciences (IUGS). Accordingly, 

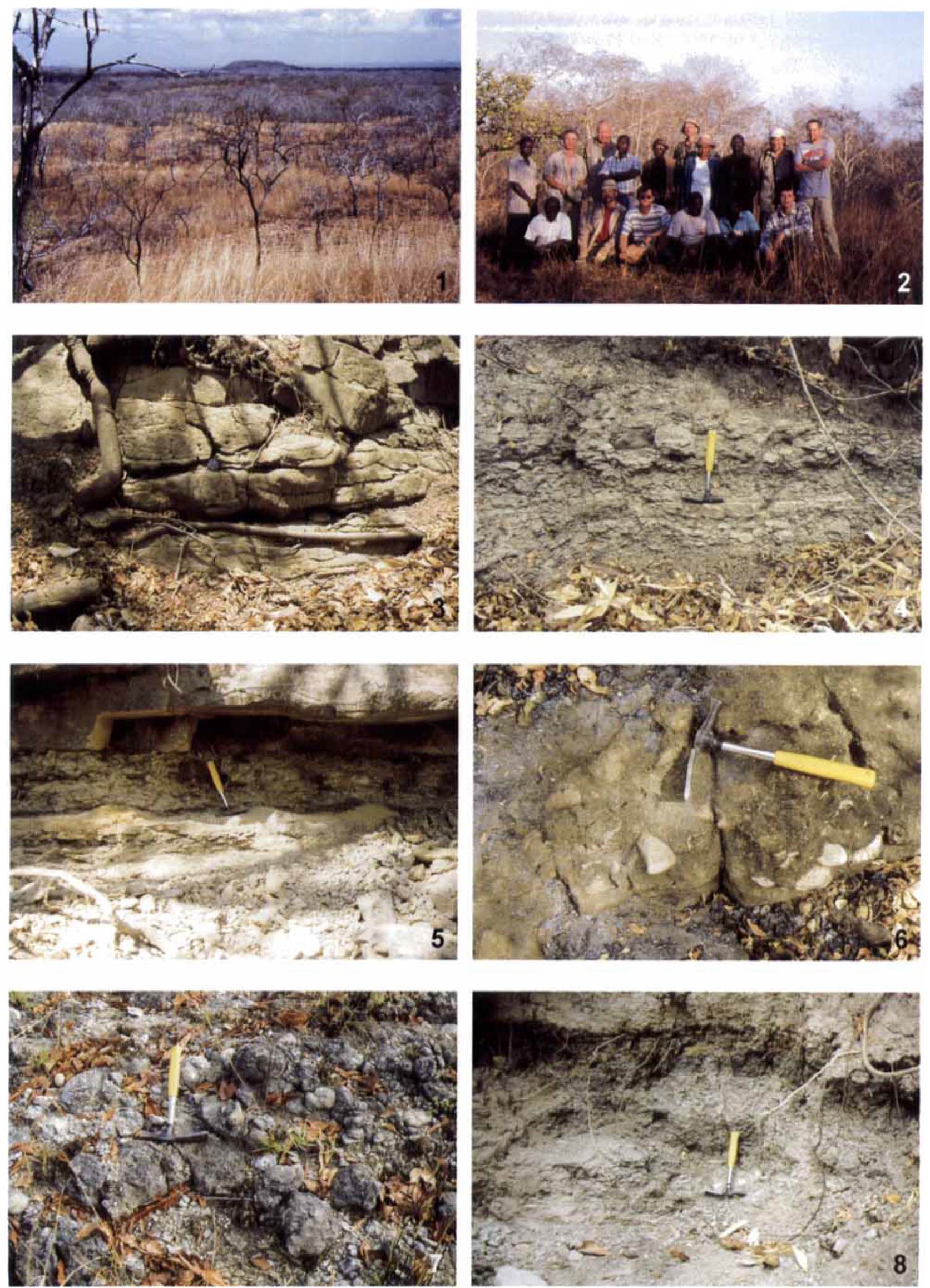
other terms were occasionally used in the literature, as, for example, Tendaguru Series (e.g., Aitken 1961), Tendaguru Formation and Middle Saurian Member (e.g., Schudack 1999). The introduction of new stratigraphic terms should be based on new geological and biostratigraphical investigations of the Jurassic and Cretaceous depositional succession in the Tendaguru region. Since these investigations have not yet been completed, we prefer for the present to adhere to the old stratigraphic designations.

\section{Invertebrates}

The macroinvertebrate fauna is dominated by bivalves, gastropods, and corals. These elements occur more or less continuously in the coarsegrained sediments at Tingutinguti, albeit mostly in low abundance. Skeletal concentrations either comprise the time-averaged, autochthonous to parautochthonous relics of once living communities or form allochthonous shell beds. Ammonites from Tendaguru Hill are rare and poorly preserved. Torquatisphinctes cf. torquatus and Taramelliceras sp. ex gr. kiderleni indicate a late Kimmeridgian age for the Nerinea Bed. Some macro-benthos samples permit quantitative analysis and can provide important palaeoecological data. As an example, one of the samples from the Trigonia smeei Bed can be interpreted as an autochthonous coral-oyster biostrome, which well illustrates a wave and current-influenced shallow, fully marine area, characterised by stable and firm substrates and a low sedimentation rate (Pl. 1: 7, Pl. 2: 4). Whereas the underlying sediment shows a regressive character, the coral-oyster biostrome obviously marks the beginning of a transgression, during which continental sediments were held back in the coastal area. The growth of the biostrome was probably terminated by an increase in siliciclastic sedimentation. A second example consists of a low diversity sample, comprising two species of bivalve and two species of gastropod. One bivalve, Eomiodon (Africomiodon) cutleri, strongly dominates the sample. Low diversity and strong dominance of a single form indicate a stressenvironment. The taxonomic composition of the sample, lack of any fully marine elements, and the marginal marine setting suggest a low-energy, brackish-water environment.

Shell beds are mostly formed by large, thickshelled specimens of the bivalve Trigonia, which are preferentially orientated in a convex-up position (Pl. 1: 6). This indicates that deposition took place under the influence of currents. The degree of boring and encrustation of shells is low, pointing to a short residence time on the sea floor before final burial. A more detailed model for the genesis of the various shell beds requires further field work and quantitative taphonomic analysis.

\section{Micropalaeontology}

The most common calcareous micro-fossils of the Tendaguru Beds are ostracods, followed by benthic foraminifers. Charophytes are rare; Clavator sp. in a sample from the Trigonia smeei Bed of the Tingutinguti stream section suggest an early Tithonian age. More detailed statements on the biostratigraphic and palaeoecologic significance of the calcareous micro-fossils will only be possible after detailed taxonomic studies have been completed.

\section{Vertebrate Palaeontology}

Research was focused primarily on microvertebrate fossils. The Lower Saurian Bed exposed in the Tingutinguti stream section was intensively investigated and sampled, but did not yield any identifiable microvertebrate remains. The Middle Saurian Bed in the Tingutinguti stream section is certainly much richer with regard to its vertebrate fossil content; several samples (containing,

Colour-Plate 1. 1. Tendaguru Hill viewed from the southeast. The Upper Jurassic dinosaur sites in the surroundings of this hill were made legendary by the German Tendaguru Expedition (1909-1913). 2. The crew of the German-Tanzanian Tendaguru Expedition 2000. Hind row from left to right: R. Chami, St. Schultka, W.-D. Heinrich, H. Kimega, S. Kapilima, G. Maier, E. Msaky, Y. Kabezi, E. Schrank, and O. Hampe; front row from left to right: J. Mhina, B. Sames, R. Bussert, O. Kamanya, E. Mgaya, and M. Aberhan. 3. Trough cross-bedded tidal channel-sandstones in the Nerinea Bed; Tingutinguti stream section. 4. Fine-grained intertidal sediments cut by a small channel, basal part of the Middle Saurian Bed; Tingutinguti stream section. 5. Conglomeratic tempestite with megaripples from the Trigonia smeii Bed; Tingutinguti stream section. 6. Bedding plane view of a monospecific shell bed of disarticulated valves of the bivalve Trigonia (Indotrigonia) oriented convex side up; small tributary of the Bolachikombe stream, about $1.5 \mathrm{~km}$ southeast of Tendaguru Hill. 7. Coral oyster biostrome; about $7 \mathrm{~km}$ northeast of Tendaguru Hill. 8. Fine-grained fluviatile and lacustrine sediments from the Upper Saurian Bed: Dwanika stream section. 

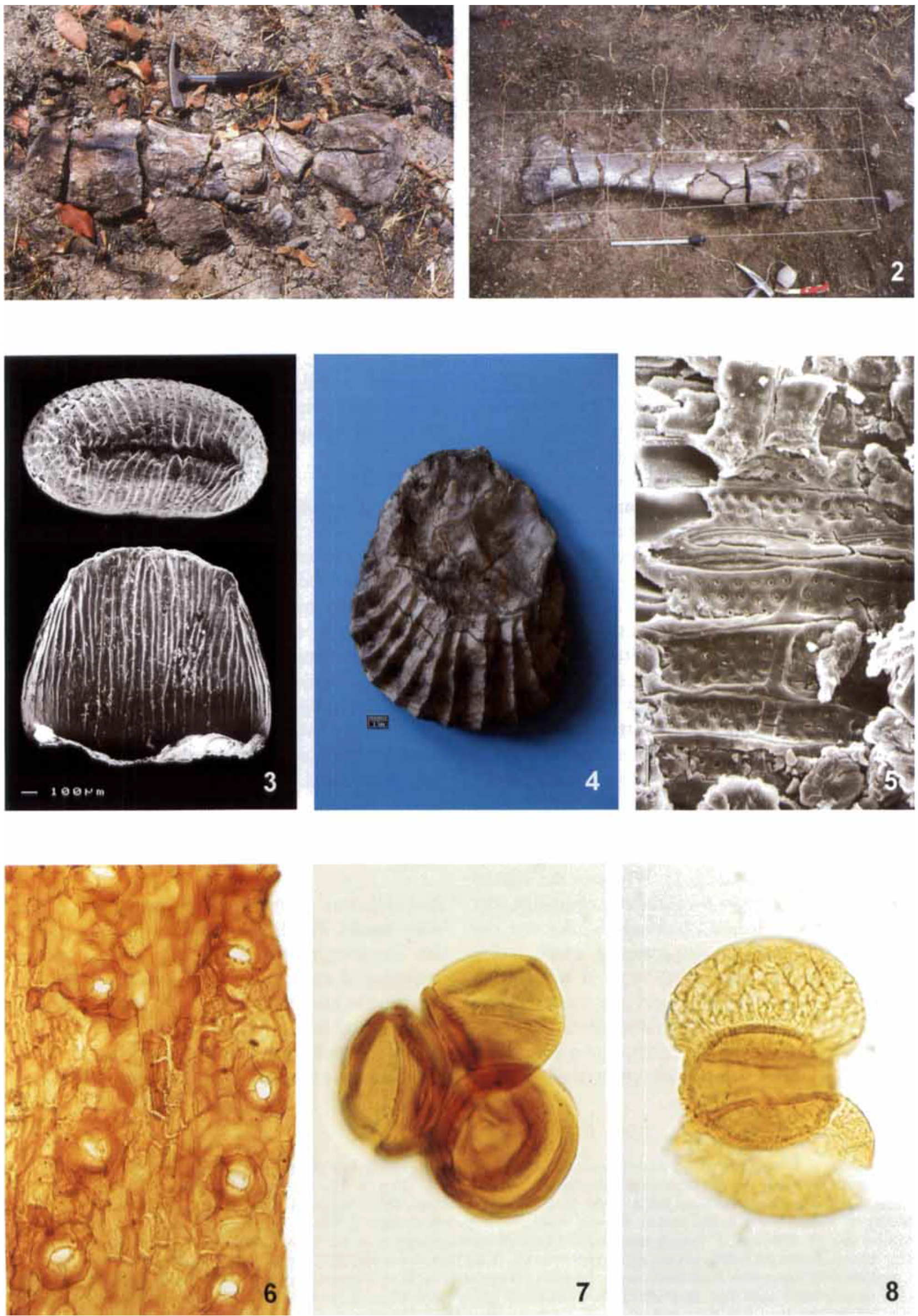

7 
for example, corals) show a clear marine influence. Microvertebrate fossils were found in several samples. Fish remains were recovered from many sections of the Middle Saurian Bed and include scales and teeth of Lepidotes, possibly belonging to Lepidotes tendaguruensis. So far, the most abundant samples of microvertebrate remains have come from the Upper Saurian Bed, exposed in the Dwanika stream section north-northwest of Tendaguru Hill. In some samples up to 50 (though often not identifiable) bone fragments of microvertebrates have been found. Single, small teeth of reptiles were present in several samples. A dwarf crocodile (?Bernissartia; Pl. 2: 3), that previously was only known from the Middle Saurian Bed (Heinrich, unpublished) is represented by isolated teeth from the Upper Saurian Bed. Isolated jaw remains and teeth, possibly of sphenodontids and a tiny dentary fragment with two alveoli of an unidentified mammal, have also been found. There is also evidence of the scales and teeth of teleost and other, as yet unidentified, fish in the samples from the Upper Saurian Bed.

The woody grassland in the region of Tendaguru Hill was intensively searched for previous quarry sites of the German and British expeditions. About 30 localities were located and exactly fixed on topographic maps, using the Global Positioning System (GPS). During the exploration, many surface finds of weathered dinosaur bones were made, but only two sauropod limb bones were worth collecting. Both limb bones, currently housed in the National Museum of Tanzania in Dar es Salaam, were found in the Upper Saurian Bed appoximately $1 \mathrm{~km}$ south of Tendaguru Hill (PI. 2: 1,2). Noteworthy is a surface accumulation consisting of about 50 fragmentary sauropod limb bones found close to a previous excavation site at the Dwanika stream valley, about $0.7 \mathrm{~km}$ north of Tendaguru Hill. The material, apparently discarded by crews of the German or British expeditions, also derives from the Upper Saurian Bed.
Among the rediscovered Tendaguru sites, two localities deserve a special note. First. Tendaguru Site IV which in June 1909, yielded the fragmentary dentary of Brancatherulum tendagurense, the first mammal to be described from the Mesozoic of Africa (Branca 1916, Dietrich 1927b). Reexamination of the ground of the pit, situated about $1 \mathrm{~km}$ south-southeast of Tendaguru Hill, and a small sandstone outrop close to this site yielded sandstone blocks showing striking similarities to the coarse grained sandstone, that produced Brancatherulum tendagurense. Unfortunately, no further mammalian remains were found at this locality during the field season 2000. Second is the exceedingly fossiliferous Tendaguru Site dy $(\mathrm{Jg}, \mathrm{Wj})$ located about $2.3 \mathrm{~km}$ north-northwest of Tendaguru Hill. It is the type locality of Dryosaurus [=Dysalotosaurus] lettowvorbecki, Staffia aenigmatica, Tendagurodon janenschi, and Tendagurutherium dietrichi, which are unrecorded elsewhere in the Tendaguru area. Large scale quarry operations carried out between 1911 and 1913 provided enormous numbers of dinosaur bones from two bone beds $(\mathrm{Jg}, \mathrm{Wj})$, intercalated within the Middle Saurian Bed. Dryosaurus bones were most abundant. Systematic research is currently being conducted on the aforementioned microvertebrates, based on matrix from these bone beds, which was collected during the original German expedition. Unfortunately, additional material could not be obtained in 2000 . since both bone-bearing strata are largely covered by overburden, and could only be exposed by using earth-moving equipment.

\section{Palaeobotany}

As illustrated by the sedimentological features discussed above, most of the sediments are of marine origin. Therefore, palaeobotanical macrofossils were not to be expected in abundance (the silicified woods from Tendaguru, mentioned for example by Janensch 1914c, Gothan 1927,

Colour-Plate 2. 1, 2. Surface finds of sauropod limb bones in the Upper Saurian Bed: about $1 \mathrm{~km}$ south of Tendaguru Hill. 3. Tooth of a crocodile (?Bernissartia sp.) from the Middle Saurian Bed (bone bed Wj) at Tendaguru Site dy in occlusal (above) and lingual view (below): MB.R.2970). 4. Exterior view of left valve of the oyster Actinostreon hennigi from the coral-oyster biostrome; about $7 \mathrm{~km}$ northeast of Tendaguru Hill; MB.M.1503. 5. Crossfield cells of Glyptostroboxylon n. sp. (fusain) from the lower part of the Upper Saurian Bed; MB.Pb.1999/595; scale $=10 \mu \mathrm{m}$. 6. Stomata surrounded by strongly cutinized cells in a Cheirolepidiacean type of cuticle from the Trigonia smeei Bed; MB.Pb.2001/1256; width of section $300 \mu \mathrm{m}$. 7. Conifer pollen from the Middle Saurian Bed: Classopollis tetrad, diameter 27 microns (aff. Cheirolepidaceae); Cyrena-Mytilus layer. Tingutinguti stream section ("below the spring"); TUB/IY12. 8. Conifer pollen from the Middle Saurian Bed: Podocarpidites ct. multesinus. diameter 64 microns (aff. Podocarpaceae); Cyrena-Mytilus layer, Tingutinguti stream section ("below the spring"); TUB/Y35. 
and Kahlert tet al. 1999 are erosional remains from the overlying Cretaceous and Tertiary sediments). Nonetheless. roughly transported mesofossils are widispread and could easily be found. Most of the mesofossils are small sized fragments of fusan mainly representing woody tissues of stems and roots. Süss \& Schultka (2001) reported the occurrence of Glyptostroboxylon tendagurense f: om the old collections in the $\mathrm{Mu}$ seum für Naturkunde. a type of wood which has now been fourd throughout the section. Another type of Glyptcstroboxylon appears in the Upper Saurian Bed (Pl. 2: 5). in addition to three new taxa, probably from the Podocarpaceae, Taxodiaceac. and one currently unidentified family. The wood occasionally shows traces of plant/plant and plant/aninal interaction. especially the destructive activities of brownrot fungi (indicating that they destroyed the protoplasma of parenchymatic ce is of the living tree) and insects. We also found perithecia of edaphic. possibly non-parasitic ungi. Special preservation of a minute hymenopteric insect, probably from the Mymaridae (parasites of wood-destroving insects), was discovered within a fragment of fusain.

Naturally m.lcerated. only slightly fragmented cuticles of gymnospermous plants are widespread. Most of the cuticles originate from the Cheirolepidiaceae ( $\mathrm{Pl}$. 2: 6). while those from Cycadaceae and Ginkgoaceac-like types are relatively rare. Al ogether there are seven different types of cuticles with a differentiated epidermal morphology. which indicates high evaporation or restricted water resources (e.g.. saline soils). In the upper part of the section. seeds of platyspermic and trigonocarpic type are found on the surface of some sandy laycrs. but their taxonomic affiliations are not yet clcar. Overall, of the nine main families of gymnosperms known from the Jurassic-Cretaceous boundary. five (cheirolepidias, taxodias. :upressas, cycads and ginkgos) are represented b: fossilised wood and/or cuticles. Previous invesigations of the Tendaguru flora in the transition interval from the Jurassic to the Cretaceous show a strong selection bias, both in the sample chrice made by the German Tendaguru Expedition of 1909-1913, and by natural taphonomic processes. Recently collected samples confirm earlier suggestions of strong selection and sorting by transport. The extreme dominance of conif ars. however. is not only the result of taphonomic processes. but might. at least partly reflect the original floral composition at Tendaguru during the Late Jurassic. This is also supported by the palynological record which yields, among others, spores of mosses and ferns. Nevertheless, there is no doubt that the Late Jurassic flora of the Tendaguru region was dominated by a diverse array of gymnosperms (Grube et al. 2001) contrasting with the well known contemporary flora of Madagascar which is dominated by horsetails and ferns (Appert 1973).

\section{Palynology}

During the German-Tanzanian Tendaguru Expedition 2000 , sections along dried up stream courses were intensively sampled because it was assumed that organic-walled microfossils (palynomorphs) were best protected from the intensive tropical weathering at these sites. As a result. palynomorphs, mainly conifer pollen, were also recovered from parts of the Tendaguru Beds (Lower and Upper Saurian Beds), that were previously regarded as palynologically non-productive. The systematic investigation of this newly discovered material is still in progress. Recently, a relatively rich palynoflora was recovered from the Trigonia schwarzi Bed (at the Namunda Plateau) overlying the Upper Saurian Bed. The presence of Cicatricosisporites, Trisaccites, Ephedripites etc. suggests an Early Cretaceous, perhaps Valanginian to Hauterivian age (Schrank 2001). Throughout the Tendaguru succession, from the Lower Saurian Bed at the base to the Trigonia schwar: $i$ Bed at the top, pollen grains of the xerophytic conifer family Cheirolepidaceae (Classopollis: PI. 2: 7) tend to be the most abundant element. indicating that semiarid conditions prevailed for a long period. Fluctuations in the dominance of different conifers, e.g., Classopollis and Araucariacites-producers in the Middle Saurian Bed. may be related to local and temporal variations in moisture levels. The presence of pollen grains of the conifer family Podocarpaceae (e.g., Podocarpidites cf. multesimus, Pl. 2: 8) is remarkable because it suggests palaeophytogeographic links to southern Gondwana.

\section{Miscellaneous}

A side product of the exploration was the discovery of lithic tools made of quartzitic rocks (c.g.. scrapers. unretouched flakes, pebble tools) irregularly scattered in the terrain around Tendaguru Hill, and now housed in the National 
Museum of Tanzania in Dar es Salaam. Similar stone tools were first discovered by W. Janensch at the Dwanika stream in 1910 and described by Werth (1916). The return to Tendaguru also provided an opportunity to conduct historical research on the various expeditions that were active at the site. Stone foundations were discovered on Tendaguru Hill, which undoubtedly represent the remnants of storage structures and dwellings occupied by German and British field workers. In Kilwa-Kivinje, a search was made for the grave of W. Bernhard Sattler, who originally brought the dinosaur remains of Tendaguru to the attention of the German authorities in 1906. Unfortunately, his resting place could not be relocated. The grave of William $\mathrm{Cu}-$ tler, who renewed excavation at Tendaguru on behalf of the British Museum (Natural History), was found in the old European cemetery in Lindi.

G. Maier, formerly a palaeontological technician, has spent many years researching the historical background of the German and British expeditions to Tendaguru. Participating in the field work at the site in 2000 was invaluable to his understanding of how previous teams had operated in the isolated location. These experiences greatly enhanced work on a book manuscript that was in progress at that time. Following the Tendaguru 2000 expedition, G. Maier continued his research in Berlin at the archives of the Institut für Paläontologie at the Museum für Naturkunde, and at the Secret State Prussian Archive. The manuscript is currently in press (Maier 2001).

\section{Future research}

One goal of this project was to collect and study skeletal remains of different vertebrates that to date, were only poorly known from the Mesozoic of Africa. Micro-mammal remains are particularly important and contribute significantly to our understanding of the origin and diversification of Mesozoic mammals in the Gondwana region. Fish fossils will provide palaeoecological data regarding the influence of marine conditions on the Tendaguru ecosystems. A second goal is, as far as possible, to develop a detailed interpretation of the Late Jurassic-Early Cretaceous Tendaguru ecosystem, by assessing, in a quantitative fashion, the taxonomic and palaeoecological data from the Tendaguru sequence. The origin of particular fossil accumulations can then be reconstructed. Thirdly, an attempt will be made to clarify the sedimentological and tectonic evolution of the sedimentary basin. Here, particular attention will be paid to the factors that controlled sedimentation and the influence of sea level fluctuations and palaeoclimate on the origin of the dinosaur Lagerstätte at Tendaguru. We plan to reconstruct the complete stratigraphic section with the help of one or more boreholes and also plan to establish a stratotype section for the Tendaguru sequence. A subsurface section will help to avoid the problem of surficial weathering, and will also provide a substantial number of samples which are fresh enough for palynological and other laboratory investigations. In addition, by expanding the studies into neighbouring areas it may be possible to discover further fossil accumulations in more terrestrial deposits, perhaps with land plants in situ or root beds. Particular effort will thus be directed toward searching for sediments of the terrestrial lithofacies type in which the collections from the years 1909-1913 were made. but which were not found in the sections studied in the 2000 pilot phase. The data collected will also be evaluated with regard to its biogeographic significance.

\section{Acknowledgements}

We convey our warmest thanks to our colleagues Prof. Abdul H. Mruma and Prof. Sospeter Muhongo from the Department of Geology of the University of Dar es Salaam for their participation in and support for this expedition. Ms. Hulda P. Gideon from the Tanzania Commission for Scienco and Technology (COSTECH) rapidly and efficiently processed the documents for us to receive Research Clcarances. Mr. Kamemba from the Antiquities Units, Dar es Salaam. kindly permitted us to collect samples and microfossils and to transfer them to Berlin. The Director of Exploration of the Tanzanian Petroleum Development Corporation (TPDC) generously provided the expedition with one additional vehicle.

Many thanks go to Prof. Hans-Peter Schultze, Museum für Naturkunde, for supporting the pilot project and presenting it to different German commissions. We thank Dr. Günter Schweigert, Staatliches Muscum für Naturkunde Stuttgart. for ammonite identifications and Dr. Michael E. Schudack. Freie Universität Berlin, for the determination of charophytes.

We are greatly indebted to the Deutsche Forschungsgemeinschaft for financial support (Projekt-Nr. SCHU 212/21-1) The expedition could not have been successfully completed without the donation of camping equipment from the firm of BIWAK, Berlin-Köpenick, and the technical cquipment sup plied by the TOOL-CO firm, Berlin-Lichtenrade. Finally. wo are most thankful to our drivers: Hassan Kimega, University of Dar es Salaam, Elvis Mgaya, TPDC and John Mhina. Omary Kamanya, and Yusufu Kabezi of Evergreen Car Rentals, for their excellent driving ability and skills and their enthusiastic contribution to our field work.

For improving the English and commenting on this paper we thank Dr. David M. Unwin, Museum für Naturkunde. 


\section{References}

Aitken. W. G. 1961. Geology and Palacontology of the Jurassic and Cretact ous of Southern Tangansika. - Geological Survey of Tancanvika Bulletin 31: 1-14t.

Appert. O. 1973. I) Pteridophyten aus dem oberen Jura des Manamana in südwest-Madagaskar. - Schweizerische Paliantologische Abhandlungen 94: $1-62$.

Arratia. G. \& Schultze. H.-P. 1999. Semionotiform fish from the Upper Jure ssic of Tendaguru (Tanzania). - Mittcilungen aus dem Museum für Naturkunde Berlin. Geowissenschaftliche Reihe 2: $1.35-153$

Beurlen. K. 1933. Crustacca Decapoda aus den TendaguruSchichten. - Falacontographica. Supplement 7. 2. Reihe (1): $87-94$.

Bonaparte, J. F. Feinrich. W.-D. \& Wild. R. 2000(). Reriew of Janenschia Will. with the description of a new sauropod from the Tend guru beds of Tanzania and a discussion on the systematic value of procoelous caudal vertebrac in the Sauropoda. - Palacontographica A 256(1-3): 25-76.

Branca. W. von 14 16. Ein Süugetier? - Interkieler aus den Tendaguru-Sch chten. - Archiv tür Biontologie 4 (1): 137-140.

Broschinski. A. 1999. Ein Lacertilier (Scincomorpha. Paramacellodidale) aus dem Oberen Jura von Tendaguru (Tansania). - Vitteilungen aus dem Museum für Naturkunde Berlin. (ieowissenschaftliche Reihe 2: 155-158.

Bussert. R. 2000. Patacoenvironmental interpretation of the Upper Jurassic-Lower Cretaceous Tendaguru Beds of southeast Tanzinia. based on petrographic investigations. - Journal of A rican Earth Sciences $30(+\mathrm{A})$ : 18.

- 2001. Die flachmarine und kontinentale Sedimentation an einer durch Gezciten. Stürme und Tsunamis(') geprägten Küste cines pissiven Kontinentalrandes (Oberjura-Lnterkreide. Sü Jost-Tansania) - Schriftenreihe der Deutschen Geclogischen Gesellschaft 13: 28-29.

Chinsamy. A. 199:. Ontogenetic changes in the hone histology of the La e Jurassic ornithopod Dryosamms lethomvorbecki. - Jounal of Vertebrate Paleontology 15 (1): $96-104$.

Christian. A. \& Heinrich. W.-D. 1998. The neck posture of Brachiosarar mancai. - Mitteilungen aus dem Museum für Naturkundo in Berlin. Goowissenschaftliche Reihe 1: $73-80$.

Christian. A.. Heiurich. W.-D. \& Golder. W. 1999a. Posture and mechanics of the forelimbs of Brachiosamms brancai (Dinosauria: Situropoda). - Mitteilungen aus dem Museum für Natutkunde Berlin. Geowissenschaftliche Reihe 2: $63-7.3$.

Christian. A.. Müller. R. H. G.. Christian. G. \& Preuschoft. H. 19996. Lim, swinging in elephants and giraffes and implications for the reconstruction of limb movements and speed csti nates in large dinosaurs. - Mitteilungen aus dem Muscum lür Naturkunde Berlin. Geowissenschaftliche Fieihe 2: $81-90$.

Dietrich. W. O. 19 t. Die Gastropoden der Tendaguruschichten. der Aptsufe und der Oberkreide im südlichen Deutsch-Ostafrka. - Archis für Biontologic 3 (t): $101-153$.

- 1925. Über eino dem mittleren Sauriermergel am Tendaguru äquivalene, rein marine Kimmeridgebildung in $\mathrm{Ma}$ hokondo. Deutsch-Ostafrika. - Palaeontographica. Supplemen1 7. 2. Rithe (1): 1-24.

- 1926. Steinkorailen des Matms und der Unterkreide im südlichen Deutich-Ostafrika. - Palaeontographica. Supplement 7. 2. $R$ sihe (1): $41-102$.

- 1927a. Das Alter der Trigonienschichten am Tendaguru. Centralblatt für Mineralogic. Geologie und Paläontologie. B 2: $59-64$.

- 1927b. Brancatienthom n. g. ein Proplacentalier aus dem ohersten Jura des Tendaguru in Deutsch-Ostafrika. Centralblatt für Mineralogic. Geologie und Paläontologie. B 10: $423-426$.
- 1933. Zur Stratigraphie und Palaeontologie der Tendaguruschichten. - Palacontographica. Supplement, 7, 2. Reihe (2): $1-86$.

Fritas. E. 1908. Ostafrikanische Dinosauricr. - Palaeontographica 55: $105-144$

Galton. P. M. 1977. The ornithopod dinosaur Dryosaurus and a Laurasia-Gondwanaland connection in the Upper Jurassic. - Nature 268: 230-232.

- 1980. Avian-like tibiolarsi of pterodactyloids (Reptilia: Pterosauria) from the Upper Jurassic of East Africa. Paliontologische Zeitschrift 54 (3/4): 331-342.

- 1981. Drvosamas. a hypsilophodontid dinosaur from the Upper Jurassic of North America and Africa. Postcranial skeleton. - Paläontologische Zeitschrift 55 (3/4): 271-312.

- 1982a. Elaphrosanmes, an ornithomimid dinosaur from the Upper Jurassic of North America and Africa. - Paläontologische Zeitschrift 56 (3/4): 265-275.

- 1982b. The postcranial anatomy of the stegosaurian dinosaur Kentrosaturts from the Upper Jurassic of Tanzania, East Africa. - Gcologica et Palacontologica 15: 139-160.

Gothan. W. 1927. Ein araucarioider Coniferenzapfen aus den Tendaguruschichten. - Palaeontographica, Supplement $\mathbf{7}$, 2. Reihe (1): 103-106.

Gross. W. 1934. Die Typen des mikroskopischen Knochenhaues bei fossilen Stegocephalen und Reptilien. - Zeitschrift lür Anatomie und Entwicklungsgeschichte 203 (6): $731-764$.

Grube. R.. Schultka. St. \& Süss. H. 2001. Kutikulen und Fusite - Hinweise auf eine oberjurassische Flora vom Tendaguru (Tansania). - Laboratorium für Paläobotanik und Palynologie. Utrecht: 29. Jahrestagung des Arbeitskreises für Paläobotanik und Palynologie (APP Tagung 2001), Programm und Beitragskurzfassungen, p. 8.

Gunga. H.-Chr.. Kirsch. K.A. \& Baartz, F. 1995. New data on the dimensions of Bractiosatiras brancai and their physiological implications. - Naturwissenschaften 82 (4): $190-192$.

Gunga. H.-Chr.. Kirsch, K., Rittweger, J., Röckcr, L., Clarke, A.. Albertz. J.. Wiedemann, A.. Mokry, S., Suthau, T., Wehr. A.. Heinrich. W.-D. \& Schultze, H.-P. 1999. Body Size and Body Volume Distribution in Two Sauropods from the Upper Jurassic of Tendaguru (Tanzania). - Mitteilungen aus dem Museum für Naturkunde Berlin, Geowissenschaftliche Reihe 2: 91-102.

Hcinrich. W.-D. 1991. Über Brancatherulam tendagurense Dietrich. 1927 (Mammalia: Eupantotheria) aus dem Oberjura von Tendaguru. Tansania. - Mitteilungen aus dem Zoologischen Museum Berlin 67 (1): 97-104.

- 1998. Late Jurassic Mammals from Tendaguru, Tanzania, East Africa. - Joumal of Mammalian Evolution 5 (4): $269-290$.

1999a. The Taphonomy of Dinosaurs from the Upper Jurassic of Tendaguru (Tanzania), Based on Ficld Sketches of the German Tendaguru Expedition (1909-1913). Mittcilungen aus dem Museum für Naturkunde Berlin, Geowissenschaftliche Reihe 2: 25-61.

- 1999b. First Haramivid (Mammalia. Allotheria) from the Mesozoic of Gondwana. - Mitteilungen aus dem Museum für Naturkunde in Berlin, Geowissenschaftliche Reihe 2: $159-170$.

Hennig. E. 1914a. Die Invertebraten-Fauna der Sauricrschichten am Tendaguru. - Archiv für Biontologic 3 (t): $155-185$.

- 1914b. Die Fischreste unter den Funden der TendaguruExpedition. - Archiv für Biontologie 3 (4): 295-312.

- 1914c. Beiträge zur Geologie und Stratigraphie DeutschOstatrikas. - I. Geologisch-stratigraphische Beobachtungen im Küstengebicte des südlichen Deutsch-Ostafrika. II. Geologisch-stratigraphische Beobachtungen im Gebiet der Jura-Ablagerungen an der Deutsch-ostafrikanischen Zentralbahn. - Arehiv für Biontologie 3 (3): 1-72.

- 1937. Der Sedimentstrcifen des Lindi-Kilwa-Hinterlandes. - Palacontographica, Supplement 7, 2. Reihc (2): 49) -186 . 
Janensch, W. 1914a. Bericht über den Verlauf der Tendaguru-Expedition. - Archiv für Biontologie 3 (1): 15-58.

- 1914b. Übersicht über die Wirbeltierfauna der TendaguruSchichten, nebst einer kurzen Charakterisierung der neu aufgestellten Arten von Sauropoden. - Archiv für Biontologie 3 (1): 79-110.

- 1914c. Die Gliederung der Tendaguruschichten im Tendagurugebiet und dic Entstchung der Saurierlagerstätten. Archiv für Biontologie 3 (3): 226-261.

- 1925. Die Grabungsstellen der Tendaguru-Gegend. - Palaeontographica, Supplement 7, 1. Reihe (1): 17-19.

- 1929. Material und Formengehalt der Sauropoden in der Ausbeute der Tendaguru-Expedition. - Palaeontographica, Supplement 7, 1. Reihe (2): 1-34.

- 1961. Skelettrekonstruktion von Dysalotosaurus lettowvorbecki. - Palaeontographica, Supplement 7, 1. Reihe (1): $237-240$.

Jarzen. D. M. 1981. A preliminary report of the palynomorphs recovered from Tendaguru hill (Tanzania). - Pollen et Spores 23 (1): 149-163.

Kahlert, E., Schultka. St. \& Süss, H. 1999. Die mesophytischc Flora der Saurierlagerstätte am Tendaguru, Tansania. Erste Ergebnisse. - Mitteilungen aus dem Museum für Naturkunde Bcrlin. Geowissenschaftliche Reihe 2: $185-199$

Kitchin, F. L. 1929. On the age of the upper and middle dinosaur-deposits at Tendaguru-Tanganyika Territory. Geological Magazine 66 (5): 193-220.

Lange, E. 1914. Die Brachiopoden, Lamellibranchiaten und Anneliden der Trigonia schwarzi-Schicht, nebst vergleichender Übersicht der Trigonien der der gesamten Tendaguru-Schichten. - Archiv für Biontologie 3 (4): $187-289$.

Maier, G. 1997. Tendaguru. In Currie, P. J. \& Padian, K. (eds). Encyclopedia of Dinosaurs: 725-726, Academic Press, San Diego.

- 2000. Tendaguru through time: the information trail of a scientific expedition. 133 pp., self-published, Calgary.

- 2001. African Dinosaurs Unearthed. The Tendaguru Expeditions. - Indiana University Press, Indianapolis. (In press)

Parkinson. J. 1930. The Dinosaur in East Africa. 188 pp., H. F. \& G. Witherby, London.

Paul. G. S. 1988. The brachiosaur giants of the Morrison and Tendaguru with a description of a new subgenus, Giraffatitan, and a comparison of the world's largest dinosaurs. - Hunteria 2 (3): 1-14.

Perry, F. S. \& Reuter, T. 1999. Hypothetical lung structure of Brachiosaurus based on functional contraints. - Mitteilungen aus dem Museum für Naturkunde Berlin, Geowissenschaftliche Reihe 2: 75-79.

Reck, H. 1931. Die deutschostafrikanischen Flugsaurier. Centralblatt für Mineralogie, Geologie und Paläontologie 1931: $321-336$.

Romer, R. L. 2000. Implication of diagenetic mobility of $\mathrm{U}$ and $\mathrm{Pb}$ on the U-Pb dating of fossils. - Berichte der Deutschen Mineralogischen Gesellschaft 2000 (1): 170. [Beiheftc zum European Journal of Mineralogy 12]
- 2001. Isotopically heterogenous inital $\mathrm{Pb}$ and continous ${ }^{222} \mathrm{Rn}-\mathrm{loss}$ in fossils: the U-Pb systematics of Brachio()saurus brancai. - Geochimica et cosmochimica acta: in print.

Russell, D., Béland, P. \& McIntosh. J. S. 1980. Paleoecology of the dinosaurs of Tendaguru (Tanzania). - Mémoires de Société Geologique de France 59 (139): 169-175.

Sander. P. M. 1999. Life History of Tendaguru Sauropods as Inferred from Long Bone Histology. - Mitteilungen aus dem Museum für Naturkunde Berlin, Geowissenschaftliche Reihe 2: 103-112.

- 2000. Long bone histology of the Tendaguru sauropods: Implications for growth and biology. - Paleobiology 26: $466-488$

Schrank, E. 1999. Palynology of the Dinosaur Beds of Tendaguru (Tanzania) - Preliminary Results. - Mitteilungen aus dem Museum für Naturkunde Berlin. Geowissenschaftliche Reihe 2: 171-183.

- 2001. Eine Expedition zur Dinosaurierlagerstätte Tendaguru (Tansania) und erste palynologische Ergebnisse. Laboratorium für Paläobotanik und Palynologie. Utrecht: 29. Jahrestagung des Arbeitskreises für Paläobotanik und Palynologie (APP Tagung 2001), Programm und Beitragskurzfassungen, p. 27.

Schudack, M. E. 1999. Some Charophytes from the Middle Dinosaur Member of the Tendaguru Formation (Upper Jurassic of Tanzania). - Mitteilungen aus dem Museum für Naturkunde Berlin. Geowissenschaftliche Reihe 2: $201-205$.

Schudack, M. E. \& Schudack, U. 2001. Ostracods from the Middle Dinosaur Member of the Tendaguru Formation (Upper Jurassic of Tanzania). - Neues Jahrbuch für Geologie und Paläontologie Monatshefte 2001: in print.

Sieverts-Doreck, H. 1939. Jura- und Kreide-Crinoideen aus Deutsch-Ostafrika. Mit einer Übersicht über jurassische Crinoideen aus Afrika und Madagaskar. - Palaeontographica, Supplement 7, 2. Reihe (2): 217-231.

Simpson, G. G. 1928. Mesozoic mammalia. XI. Brancatherulum tendagurense Dietrich. - American Joumal of Science 15 (88): $303-308$.

Süss, H. \& Schultka, St. 2001. First record of Glyptostroborylon from the Upper Jurassic of Tendaguru. Tanzania. Botanical Journal of the Linnean Society 135: 421-429.

Unwin. D. M. \& Heinrich, W.-D. 1999. On a Pterosaur Jaw from the Upper Jurassic of Tendaguru (Tanzania). - Mitteilungen aus dem Museum für Naturkunde Berlin. Geowissenschaftliche Reihe 2: 121-134.

Werth, E. 1916. Dic ersten Spuren des fossilen Menschen in Deutsch-Ostafrika. - Sitzungsberichte der Gesellschaft Naturforschender Freunde, Berlin: 40-42.

Wiedemann. A.. Suthau, T. \& Albertz. J. 1999. Photogrammetric Survey of Dinosaur Skeletons. - Mitteilungen aus dem Museum für Naturkunde Berlin, Geowissenschaftliche Reihe 2: 113-119.

Zils, W., Werner, C. Moritz, A. \& Saanane, C. 1995. Orientierende Tendaguru-Expedition 1994. - Bcrliner geowissenschaftliche Abhandlungen E16: 483-531.

Zwierzycki, J. 1914. Die Cephalopodenfauna der TendaguruSchichten in Deutsch-Ostafrika. - Archiv für Biontologie $3(4)$ : 7-96. 